\title{
PERTUMBUHAN DAN HASIL TANAMAN CABAI BESAR (Capsicum annuum L.) DENGAN PEMBERIAN MIKORIZA DAN MIKROORGANISME LOKAL BONGGOL DAN BATANG PISANG
}

\section{(Growth and Yield of Red Chili (Capsicum annuum L.) by Giving Mycorrhizae and Local Microorganisms Weevil and Banana Stem)}

\begin{abstract}
Alvera Prihatini Dewi Nazari , Eliyani1 ${ }^{1}$, Akbar ${ }^{2}$
${ }^{1}$ Dosen dan ${ }^{2}$ Mahasiswa Program Studi Agroekoteknologi, Fakultas Pertanian, Universitas Mulawarman, Jalan Pasir Balengkong Kampus Gunung Kelua, Universitas Mulawarman Samarinda 75119, Indonesia. Penulis Koresponden: alverapdn@gmailcom
\end{abstract}

Article Submitted : 17-12-2021

Article Accepted : 10-01-2022

\begin{abstract}
The research was conducted to find out the effect of interaction; mycorrhizal dosage; and local microorganisms of weevil and banana stems on the growth and yield of red chili. The experiment was conducted from February to June 2020 in Loa Bakung Village, Sungai Kunjang Subdistrict, Samarinda, arranged in a Randomized Complete Block Design consisted of two factors and replicated seven times. The first factor was mycorrhizal dose, consisted of four levels: $0 ; 5 ; 10$; and $15 \mathrm{~g} \mathrm{plant}^{-1}$. The second factor was the concentration of local microorganisms, consisted of four levels, namely: $0 \mathrm{~mL} \mathrm{~L}^{-1}$ (100\% water);100; 200; and 300 $\mathrm{mL} \mathrm{L} \mathrm{L}^{-1}$. The results showed that the interaction between mycorrhizae and MOL was significantly different on fresh fruit weight and fruit dry weight with the best treatment being 10 g mycorrhizal plant ${ }^{-1}$ and $200 \mathrm{ml} \mathrm{MOL} \mathrm{L}^{-1}$ on fresh fruit weight and dry fruit weight, 303.14 and $36.86 \mathrm{~g} \mathrm{plant}^{-1}$. The effect of mycorrhizae was significantly different on fresh fruit weight, fruit dry weight, fruit diameter, and fruit length, with the best dose was $10 \mathrm{~g}$ mycorrhizal plant ${ }^{-1}$, obtained fruit fresh weight $229.42 \mathrm{~g}$ and fruit dry weight $26.77 \mathrm{~g}$. The effect of MOL was significantly different on the number of fruit, fruit fresh weight, fruit dry weight, fruit diameter, and fruit length, with the best concentration was $200 \mathrm{~mL} \mathrm{MOL} \mathrm{L}^{-1}$ obtained fresh fruit weight of $256.53 \mathrm{~g}$ and fruit dry weight $29.98 \mathrm{~g}$.
\end{abstract}

Keywords: Banana Weevil and Stems, Local Microorganisms, Miychorrihzae, Red chili.

\section{PENDAHULUAN}

Cabai merupakan ta $\mathrm{n}$ a man sayuran yang bernilai ekonomi tinggi, selain dikonsumsi sehari-hari oleh masyarakat, juga untuk bahan baku industri pangan dan farmasi, sehingga permintaan akan komoditas ini terus meningkat. Permintaan yang terus meningkat menuntut meningkatnya produktivitas cabai besar, akan tetapi data produktivitas cabai besar di Kalimantan Timur dari tahun 2015-2019 sebesar 6,00; 4,78; 4,82; 5,12; dan 5,98 Mg $\mathrm{ha}^{-1}$, selalu lebih rendah daripada produktivitas nasional yang mencapai 8,65 ; 8,47; 8,46; 8,77; dan 9,10 $\mathrm{Mg} \mathrm{ha}^{-1}$ dalam kurun waktu yang sama (Kementan). Faktor penyebab rendahnya produksi cabai besar diantaranya adalah tingkat kesuburan tanah yang relatif rendah, sehingga pertumbuhannya tidak optimal dan hasil tanaman tidak maksimal, sehingga perlu dilakukan pemupukan.

Pupuk adalah bahan yang diberikan ke tanah/tanaman yang mengandung unsur 
hara (satu atau lebih) untuk mencukupi kebutuhan tanaman agar pertumbuhannya optimal dan produksinya maksimal (Balitbangtan, 2015). Selama beberapa dekade, petani sangat tergantung kepada pupuk anorganik untuk mendapatkan produksi tanaman yang maksimal, padahal penggunaan secara kontinyu dapat merusak tanah, seperti pemadatan tanah, berkurangnya kandungan unsur hara dalam tanah, dan tingginya kemasaman tanah yang berdampak buruk terhadap kehidupan mikroorgansme tanah, serta tercemarnya lingkungan (Alex, 2013).

Pupuk hayati merupakan alternatif untuk memenuhi kebutuhan nutrisi tanaman tanpa menyebabkan kerusakan tanah dan lingkungan. Menurut Kurnia (2014) bahwa pupuk tersebut mengandung organisme hidup yang memperbaki ketersediaa nutrisi bagi tanaman secara perlahan/bertahap, baik melalui fiksasi $\mathrm{N}_{2}$ dari udara, melarutkan fosfat, maupun sintesis zat-zat yang diperlukan tanaman, sehingga siklus menyuburkan tanah akan berlangsung secara berkesinambungan. Dua diantara beberapa macam pupuk hayati adalah mikoriza dan Mikroorganisme Lokal (MOL)

Mikoriza adalah bentuk simbiosis yang saling menguntungkan dimana tanaman inang mendapat manfaat dari asosiasi ini, yaitu meningkatkan kelarutan unsur hara dan pelapukan bahan induk, penyerapan unsur hara dan air, melindungi tanaman dari patogen akar, dan memperbaiki struktur tanah (Subiksa, 2002). Sedangkan MOL adalah larutan hasil fermentasi yang bahan dasarnya berasal dari sumber daya setempat, mengandung unsur hara makro dan mikro, perangsang pertumbuhan, dan pengendali hama dan penyakit tanaman, sehingga dapat dipakai sebagai fungisida hayati, serta mikroba yang berfungsi sebagai dekomposer (Purwasasmita dan Kunia, 2009). Selain kelebihan tersebut, biaya pembuatan MOL murah karena bahan pembuatannya banyak tersedia di sekitar kita, diantaranya bonggol dan batang pisang.

MOL bonggol pisang mengandung ZPT gibberelin dan sitokinin serta mikroba dekomposer, diantaranya Bacillus sp., Aspergillus niger, dan Aeromonas sp. (Maspary, 2012), sedangkan pupuk organik cair (POC) batang pisang mengandung nitrogen dan fosfor masing-masing sebesar $0,02 \%$ dan $511,30 \mathrm{mg} \mathrm{kg}^{-1}$ (Budiyani et al, 2016). Suhastyo (2011) mengisolasi mikroba yang terdapat dalam MOL bonggol pisang, diantaranya adalah Bacillus sp., yaitu bakteri pelarut fosfat, berperan dalam nitrifikasi dan denitrifikasi, perombakan senyawa organik, dapat menghasilkan antibiotika, dan sebagai agen pengendali hayati.

\section{METODE PENELITIAN}

\section{Waktu dan Tempat}

Penelitian dilaksanakan dari bulan Februari sampai dengan Juni 2020 di Kelurahan Loa Bakung, Kecamatan Sungai Kunjang, Samarinda.

\section{Bahan dan Alat}

Bahan penelitian : benih tanaman cabai besar varietas Landung, pupuk kotoran kambing, pupuk mikoriza, gula merah, air kelapa, bonggol dan batang pisang.

Alat penelitian : polibag, ajir, mesin pemotong rumput, cangkul, parang, timbangan, selang, plastik, ember, meteran, kamera, dan alat tulis.

\section{Rancangan Penelitian}

Penelitian menggunakan RAK pola faktorial $4 \mathrm{x} 4$ yang diulang sebanyak tujuh kali. Faktor pertama adalah dosis mikoriza (M), terdiri atas empat taraf, yaitu : $\mathrm{m}_{0}=0$ $\mathrm{g}_{\text {tanaman }}-1 ; \mathrm{m}_{1}=5 \mathrm{~g}$ tanaman $^{-1} ; \mathrm{m}_{2}=10$

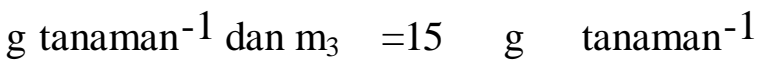
Faktor kedua adalah konsentrasi MOL (P), terdiri atas empat taraf, yaitu : $\mathrm{p}_{0}=0$ $\mathrm{mL} \mathrm{L}^{-1}$ (100\% air); $\mathrm{p}_{1}=100 \mathrm{~mL} \mathrm{~L}^{-1} ; \mathrm{p}_{2}$ $=200 \mathrm{~mL} \mathrm{~L}^{-1}$ dan $\mathrm{p}_{3}=300 \mathrm{~mL} \mathrm{~L}^{-1}$ 


\section{Prose dur Pelaksanaan Penelitian Persiapan Bibit}

Benih terlebih dahulu dengan cara direndam selama 3-4 jam dalam air. Benih yang tenggelam dipilih dan disemai pada media persemaian berupa campuran 1: 1 tanah dan pupuk kotoran kambing.

\section{Persiapan Media Tanam}

Media tanam berupa campuran $2: 1$ : 1 (tanah, pupuk kotoran kambing, dan sekam) yang diisikan ke dalam polybag berukuran $40 \mathrm{~cm} \quad x \quad 50 \mathrm{~cm}$, kemudian polybag diatur dengan jarak $50 \mathrm{~cm}$ x $80 \mathrm{~cm}$.

\section{Pindah Tanam}

Pindah tanam dilakukan setelah bibit berumur \pm 14 hari dan mempunyai empat helai daun (sehat dan seragam), masingmasing satu bibit setiap polybag.

\section{Pemberian Perlakuan}

a. Pupuk Hayati Mikoriza

Mikoriza diberikan dengan cara diletakkan pada bagian perakaran bibit sesuai dengan dosis masing-masing perlakuan pada saat pindah tanam.

b. Mikroorganisme Lokal

Mikroorganisme Lokal (MOL) bonggol dan batang pisang diaplikasikan (disemprotkan) ke tubuh tanaman sebanyak lima kali $(14,28,42,56$, dan 70 HST sesuai dengan konsentrasi masing-masing perlakuan dengan dosis $250 \mathrm{~mL}^{\text {tanaman }}{ }^{-1}$.

\section{Pemeliharaan}

Pemeliharaan tanaman : penyiraman, penyulaman, pemasangan ajir, pengendalian hama dan penyakit, serta penyiangan gulma.

\section{Panen}

Panen dilakukan jika buah padat, berisi, dan apabila ditekan, tekstur buah keras, dan $50 \%$ bagian buah berwarna merah. Panen dilakukan dengan interval lima hari.

\section{Variabel yang Diamati}

Variabel yang diamati : pertambahan tinggi tanaman pada umur 14, 42, dan 70 HST, jumlah cabang pada saat panen, umur berbunga, umur berbuah, jumlah buah, bobot segar buah, bobot kering buah, diameter buah, dan panjang buah.

\section{Analisis Data}

Data dianalisis menggunakan sidik ragam pada taraf $5 \%$, dilanjutkan dengan Uji Jarak Berganda Duncan pada taraf 5\% untuk membandingkan antara dua rata-rata perlakuan.

\section{HASIL DAN PEMBAHASAN}

\section{Interaksi Antara Mikoriza dan MOL Bonggol dan Batang Pisang}

Hasil penelitian menunjukkan bahwa interaksi antara dosis mikoriza dan konsentrasi MOL bonggol dan batang pisang berbeda nyata terhadap bobot segar buah dan bobot kering buah (Tabel 2), yang disebabkan melalui hifanya yang berukuran lebih halus dan panjang daripada akar tanaman, mikoriza membantu tanaman meningkatkan absorbsi air dan unsur $\mathrm{N}, \mathrm{P}$, $\mathrm{K}$, dan S. Pengamatan secara visual pada akhir penelitian menunjukkan adanya hifa di sekitar akar tanaman yang diberi perlakuan mikoriza. Menurut Killham (1994), hifa eksternal yang halus mampu menembus ke dalam pori-pori mikro tanah dan membantu meningkatkan penyerapan air.

Subiksa (2002) menambahkan, bersamaan dengan penyerapan air, unsur hara yang larut $(\mathrm{N}, \mathrm{K}$, dan $\mathrm{S})$ akan terbawa oleh aliran masa, sehingga penyerapannya oleh tanaman akan meningkat. Selain itu, hifa mikoriza menghasilkan enzim fosfatase yang dapat merubah $\mathrm{P}$ terikat menjadi $\mathrm{P}$ tersedia. Mikoriza membantu memperbaiki dan memantapkan struktur tanah, sehingga agregat tanah menjadi lebih baik, pori-pori tanah lebih banyak, dan permeabilitasnya meningkat, serta mempunyai kapasitas memegang air yang cukup, sehingga kelembapan tanah terjaga. Aerasi dan infiltrasi meningkat, sehingga erosi tanah berkurang, sehingga berdampak positif untuk tanaman (Thomas et al, 1993). 
Tabel 1. Rekapitulasi Data dan Hasil Analis is Data Penelitian Pertambahan Tinggi Tanaman, Jumlah Cabang, dan Umur Berbunga Tanaman Cabai Besar

\begin{tabular}{|c|c|c|c|c|c|}
\hline Perlakuan & \multicolumn{3}{|c|}{$\begin{array}{c}\text { Pertambahan Tinggi Tanaman } \\
(\mathrm{cm})\end{array}$} & $\begin{array}{c}\text { Jumlah } \\
\text { Cabang } \\
\text { (cabang) }\end{array}$ & $\begin{array}{c}\text { Umur } \\
\text { Berbunga } \\
\text { (HST) }\end{array}$ \\
\hline \multicolumn{6}{|l|}{$\begin{array}{c}\text { Dosis } \\
\left.\operatorname{tanaman}^{-1}\right)\end{array}$} \\
\hline Sidik Ragam & tn & $\operatorname{tn}$ & tn & tn & tn \\
\hline $\mathrm{p}_{0}=0$ & 4,24 & 16,09 & 10,02 & 4,29 & 46,18 \\
\hline$p_{1}=5$ & 3,77 & 15,31 & 10,45 & 4,54 & 46,43 \\
\hline $\mathrm{p}_{2}=10$ & 3,68 & 16,22 & 11,76 & 4,07 & 46,21 \\
\hline $\mathrm{p}_{3}=15$ & 4,24 & 14,96 & 12,04 & 5,32 & 47,78 \\
\hline \multicolumn{6}{|c|}{ Konsentrasi MOL (P) (mL L $\left.{ }^{-1}\right)$} \\
\hline Sidik Ragam & tn & $*$ & tn & tn & tn \\
\hline $\mathrm{m}_{0}=0$ & 4,08 & $16,79^{c}$ & 11,54 & 4,61 & 46,00 \\
\hline$m_{1}=100$ & 3,96 & $17,14^{\mathrm{C}}$ & 10,01 & 4,47 & 46,43 \\
\hline $\mathrm{m}_{2}=200$ & 4,30 & $15,76^{\mathrm{B}}$ & 11,51 & 4,86 & 46,78 \\
\hline $\mathrm{m}_{3}=300$ & 3,59 & $12,89^{\mathrm{A}}$ & 11,20 & 4,29 & 47,39 \\
\hline \multicolumn{6}{|l|}{ Interaksi ( M x P) } \\
\hline Sidik Ragam & tn & tn & tn & tn & tn \\
\hline $\mathrm{m}_{0} \mathrm{p}_{0}$ & 4,96 & 14,07 & 9,81 & 4,71 & 47.57 \\
\hline$m_{0} p_{1}$ & 3,31 & 18,97 & 9,83 & 3,71 & 45,57 \\
\hline $\mathrm{m}_{0} \mathrm{p}_{2}$ & 5,60 & 16,61 & 11,23 & 4,86 & 45,14 \\
\hline $\mathrm{m}_{0} \mathrm{p}_{3}$ & 3.09 & 14.71 & 9.19 & 3.86 & 46,43 \\
\hline$m_{1} p_{0}$ & 4,19 & 17,64 & 12,09 & 5,00 & 45,14 \\
\hline$m_{1} p_{1}$ & 3,49 & 14,36 & 9,86 & 2,86 & 46,00 \\
\hline$m_{1} p_{2}$ & 3,90 & 13,93 & 12.83 & 6,29 & 48,14 \\
\hline$m_{1} p_{3}$ & 3,51 & 15,29 & 7.00 & 4.00 & 46,43 \\
\hline $\mathrm{m}_{2} \mathrm{p}_{0}$ & 3,21 & 20,39 & 12,34 & 3,71 & 44,71 \\
\hline$m_{2} p_{1}$ & 3,96 & 19,29 & 10,60 & 4,43 & 46,43 \\
\hline$m_{2} p_{2}$ & 3.66 & 16.07 & 9.10 & 3,43 & 46,14 \\
\hline $\mathrm{m}_{2} \mathrm{p}_{3}$ & 3.90 & 9.14 & 14.99 & 4.71 & 47.57 \\
\hline $\mathrm{m}_{3} \mathrm{p}_{0}$ & 3.97 & 15.07 & 1190 & 5,00 & 46.57 \\
\hline$m_{3} p_{1}$ & 5.07 & 15.94 & 9.73 & 6.86 & 47.71 \\
\hline $\mathrm{m}_{3} \mathrm{p}_{2}$ & 4.04 & 16.41 & 12.89 & 4.86 & 47.71 \\
\hline $\mathrm{m}_{3} \mathrm{p}_{3}$ & 3,87 & 12,43 & 13,63 & 4,57 & 49,14 \\
\hline
\end{tabular}

Keterangan: Angka rata-rata yang diikuti oleh huruf yang sama menunjukkan berbeda tidak nyata dengan UJBD taraf $5 \%$.

Selain peran mikoriza, MOL bonggol dan batang pisang mengandung unsur hara makro dan mikro, sesuai dengan hasil penelitian Suhastyo (2011), yang mendapatkan unsur $\mathrm{N}, \mathrm{P}, \mathrm{K}, \mathrm{Ca}$, dan $\mathrm{Mg}, \mathrm{Fe}$,
$\mathrm{Cu}, \mathrm{Zn}$, dan $\mathrm{Mn}$ dalam MOL bonggol pisang, keong mas, dan urine kelinci dengan kadar yang berbeda. Perbedaan kadar unsur hara dalam MOL disebabkan oleh bahan sumber MOL.

Tabel 2. Rekapitulasi Data dan Hasil Analis is Data Penelitian Umur Berbuah, Jumlah Buah, Bobot Segar Buah, Bobot Kering Buah, Diameter Buah, dan Panjang Buah Tanaman Cabai Besar

\begin{tabular}{|c|c|c|c|c|c|c|}
\hline Perlak uan & $\begin{array}{l}\text { Umur } \\
\text { Berbuah } \\
\text { (HST) }\end{array}$ & $\begin{array}{l}\text { Jumlah } \\
\text { Buah } \\
\text { Tanaman }^{-1} \\
\text { (buah) }\end{array}$ & $\begin{array}{c}\text { Bobot } \\
\text { Segar } \\
\text { Buah } \\
(\mathrm{g}) \\
\end{array}$ & $\begin{array}{l}\text { Bobot } \\
\text { Kering } \\
\text { Buah } \\
(\mathrm{g}) \\
\end{array}$ & $\begin{array}{l}\text { Diameter } \\
\text { Buah }(\mathrm{cm})\end{array}$ & $\begin{array}{l}\text { Panjang } \\
\text { Buah }(\mathrm{cm})\end{array}$ \\
\hline $\begin{array}{rrl}\text { Dosis } & \text { Mikoriza } & (\mathrm{M})(\mathrm{g} \text { tanam an } \\
& \text { Sidik Ragam } \\
& \text { Rag }\end{array}$ & tn & tn & $*$ & $*$ & $*$ & $*$ \\
\hline $\mathrm{p}_{0}=0$ & 50,11 & 28,96 & $197,28^{a}$ & $22,49^{a}$ & $1,78^{\circ}$ & $9,14^{c}$ \\
\hline$p_{1}=5$ & 50,25 & 28,57 & $204,85^{b}$ & $23,40^{\mathrm{b}}$ & $1,76^{\mathrm{a}}$ & $9,07^{\mathrm{b}}$ \\
\hline $\mathrm{p}_{2}=10$ & 50,25 & 30,18 & $229,42^{d}$ & $26,77^{\mathrm{d}}$ & $1,86^{\mathrm{c}}$ & $8,95^{\mathrm{a}}$ \\
\hline $\mathrm{p}_{3}=15$ & 51,64 & 28,86 & $224,18^{\mathrm{c}}$ & $25,63^{\mathrm{c}}$ & $1,78^{\mathrm{b}}$ & $9,26^{\mathrm{d}}$ \\
\hline $\begin{array}{c}\text { Konsentrasi MOL (P) }\left(\mathrm{mL} \mathrm{L} \mathrm{L}^{-1}\right) \\
\text { Sidik Ragam }\end{array}$ & tn & $*$ & $*$ & $*$ & $*$ & $*$ \\
\hline
\end{tabular}




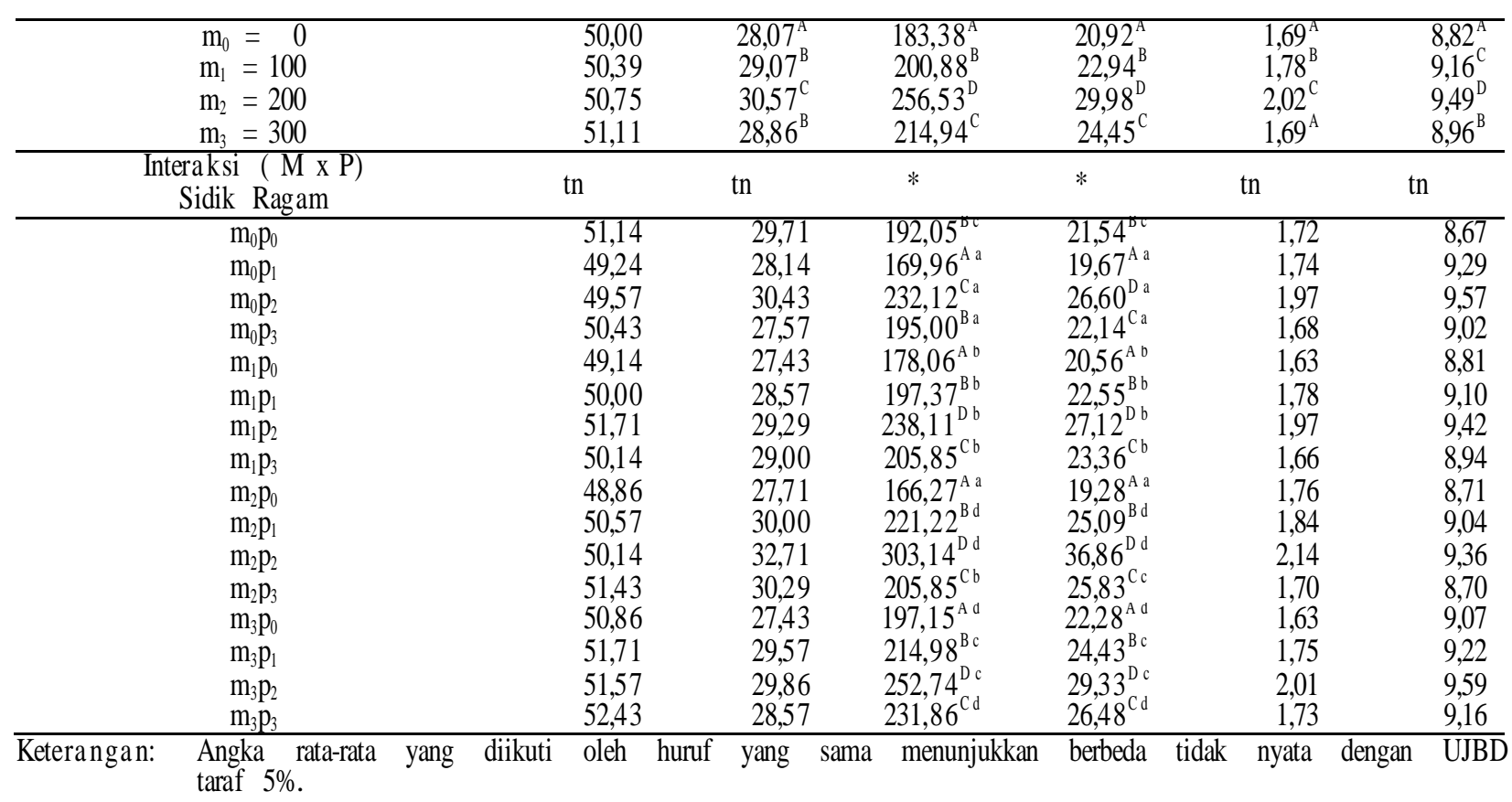

Selain unsur hara, MOL juga mengandung ZPT giberelin dan sitokinin, serta mikroorganisme menguntungkan. Peran giberelin diantaranya adalah dalam pembentukan dan pematangan buah (fruit set dan fruit ripening), sedangkan sitokinin berperan memacu pembelahan dan diferensiasi sel, serta pembentukan organ. Hasil isolasi dan identifikasi mikroorganisme dalam MOL bonggol dan batang pisang pada penelitian ini menunjukkan adanya Bacillus sp., Aspergillus niger, dan Aerobasidium. Bacillus sp. adalah bakteri pelarut fosfat, berperan dalam nitrifikasi dan denitrifikasi, perombakan senyawa organik, dapat menghasilkan antibiotika, dan sebagai agen pengendali hayati (Soesanto, 2008), terbukti mampu menekan pertumbuhan bakteri patogen Ralstonia solanacearum dan meningkatkan pertumbuhan bibit dan tanaman cabai (Resti et al, 2019), sedangkan Aspergillus niger adalah salah satu fungi pelarut $\mathrm{P}$ yang dominan pada tanah masam di Indonesia (Goenadi dan Saraswati, 1993) .

Interaksi antara mikoriza dan MOL berbeda tidak nyata terhadap pertambahan tinggi tanaman, jumlah cabang, umur berbunga, umur berbuah, jumlah, diameter dan panjang buah, diduga berhubungan dengan cara bekerja mikoriza dan MOL sebagai pupuk hayati yang bekerja secara perlahan dalam meningkatkan kesuburan tanah dan ketersediaan ketersediaan nutrisi bagi tanaman (Kurnia, 2014). Walaupuan interaksi antara dosis mikoriza dan konsentrasi MOL bonggol dan batang pisang berbeda tidak nyata terhadap semua pengamatan, namun kombinasi mikoriza dengan dosis $10 \mathrm{~g} \operatorname{tanaman}^{-1}$ dan MOL dengan konsentrasi $200 \mathrm{~mL} \mathrm{~L}^{-1}$ memberikan hasil cabai besar yang lebih baik.

\section{Pertumbuhan dan Hasil Tanaman Cabai Besar (Capsicum annuum L.) dengan Pemberian Mikoriza}

Perlakuan dosis mikoriza be rbeda tidak nyata terhadap pertambahan tinggi tanaman, jumlah cabang, umur berbunga dan umur berbuah, dan jumlah buah per tanaman (Tabel 1 dan 2) diduga karena selain dipengaruhi oleh tanaman dan cendawan, respons tanaman terhadap mikoriza juga dipengaruhi oleh faktor lingkungan tempat tumbuhnya, sebagaimana dikemukakan oleh Solaiman dan Hirata (1995), efektivitas mikoriza dipengaruhi oleh faktor abiotik ( $\mathrm{pH}$, unsur hara, kadar air, suhu, pengolahan tanah, serta pemakaian pupuk dan pestisida; dan faktor biotik 
(interaksi antara mikroba, jenis cendawan, jenis dan tipe akar tanaman inang, dan persaingan antar cendawan dari lingkungan tanahnya).

Analisis kimia terhadap media tanam diketahui bahwa kadar unsur hara media tanam mengandung $\mathrm{N}$-total $0,06 \%$ (sangat rendah), $\quad \mathrm{P}_{2} \mathrm{O}_{5}$ tersedia $10,46 \mathrm{ppm}$ (rendah), dan $\mathrm{K}_{2} \mathrm{O}$ tersedia $103,87 \mathrm{ppm}$ (sangat tinggi), serta $\mathrm{pH}$ tanah 4,16 (sangat masam). $\mathrm{pH}$ yang rendah menyebabkan $\mathrm{P}$ tidak tersedia karena difiksasi oleh $\mathrm{Al}$, beberapa unsur-unsur mikro menjadi mudah larut, sehingga kadarnya berlebihan dan menjadi racun bagi tanaman, serta menghambat pertumbuhan dan perkembangan mikroorganisme, khususnya bakteri. Hal ini dijelaskan oleh Hardjowigeno (1995) bahwa pH tanah sangat menentukan ketersediaan unsur hara bagi tanaman, mengindikasikan adanya unsur-unsur beracun, serta mempengaruhi perkembangan mikroorganisme dalam tanah.

Selain faktor-faktor di atas, mikoriza merupakan pupuk hayati yang bekerja secara perlahan dalam memperbaiki kesuburan tanah, sebagaimana dikemukakan oleh Kurnia (2014), pupuk hayati dapat meningkatkan kesuburan tanah dan ketersediaan unsur hara secara perlahan secara perlahan, sehingga pengaruhnya baru terlihat setelah melewati fase pertumbuhan vegetatif.

Pengaruh dosis mikoriza be rbeda nyata terhadap buah cabai besar (bobot segar, bobot kering buah, diameter dan panjang). Hal ini diduga berhubungan dengan cara bekerja mikoriza yang merupakan pupuk hayati. Mikoriza bekerja secara perlahan dalam meningkatkan kesuburan tanah dan menyediakan nutrisi bagi tanaman, sehingga pengaruhnya pada fase pertumbuhan vegetatif belum nyata perbedaannya. Tabel 1 dan 2 menunjukkan bahwa walaupun pengaruhnya berbeda tidak nyata pada fase pertumbuhan vegetatif, tetapi perlakuan $10 \mathrm{~g}$ mikoriza tanaman ${ }^{-1}$ memberikan hasil buah (diameter, bobot segar,dan bobot kering) yang lebih tinggi dan nyata dibandingkan dosis lainnya). Sesuia dengan laporan penelitian Matondang et al (2020) bahwa perlakuan $10 \mathrm{~g}$ mikoriza tanaman $^{-1}$ pada tanah andosol menghasilkan tanaman cabai besar yang lebih baik.

\section{Pertumbuhan dan Hasil Tanaman Cabai Besar (Capsicum annuum L.) dengan Pemberian Mikroorganisme Lokal (MOL) Bonggol dan Batang Pisang}

\section{Perlakuan konsentrasi MOL}

berbeda nyata terhadap jumlah buah per tanaman, bobot segar, bobot kering, diameter, dan panjang buah, tetapi berbeda tidak nyata terhadap pertambahan tinggi tanaman, jumlah cabang, umur berbunga, dan umur berbuah (Tabel 1 dan 2)

Sebagaimana halnya mikoriza, tidak adanya pengaruh MOL terhadap pertumbuhan vegetatif tanaman, umur berbunga dan umur berbuah. Hal ini diduga berhubungan dengan sifat MOL sebagai pupuk hayati yang bekerja secara perlahan dalam menyediakan nutrisi bagi tanaman, sehingga pengaruhnya terhadap tanaman memerlukan waktu dan baru terlihat pada hasil tanaman. Selain itu, $\mathrm{pH}$ dan kadar unsur MOL umumnya rendah. Sebagaiman laporan penelitian Eliyani et al (2018) bahwa hasil analisis laboratorium POC limbah rumah tangga mempunyai $\mathrm{pH}$ rendah, yaitu 3,3, serta mengandung unsur $\mathrm{N}, \mathrm{Fe}, \mathrm{Mn}, \mathrm{Cu}, \mathrm{Zn}, \mathrm{B}$, dan Co, meskipun $\mathrm{P}$ dan $\mathrm{K}$ tidak dianalisis, tetapi kedua unsur tersebut diyakini ada dalam POC tersebut.

Rendahnya $\mathrm{pH}$ MOL bonggol dan batang pisang disebabkan pada proses perombakan karbohidrat secara anaerob akan menghasilkan asam-asam organik (asetat, piruvat dan laktat) dan juga asam karbonat. Konsentrasi asam organik dan ion $\mathrm{H}^{+}$yang tinggi menyebabkan $\mathrm{pH}$ larutan MOL rendah. Hal ini diperkuat oleh Suhastyo (2011) dengan hasil penelitiannya yang menunjukkan bahwa MOL bonggol pisang mempunyai $\mathrm{pH}$ yaitu 4,5 , sedangkan 
MOL urine kelinci dan keong mas (kaya protein), masing-masing 4,6 dan 6,1.

Kadar unsur hara MOL dan media tanam yang rendah serta cara bekerjanya yang perlahan, menyebabkan ketersediaan nutrisi bagi tanaman menjadi lambat, sehingga pengaruh MOL baru terlihat pada variabel yang berkaitan dengan hasil tanaman (jumlah, bobot segar, bobot kering, diameter dan panjang buah). Tabel 1 dan 2 memperlihatkan bahwa walaupun pengaruhnya berbeda tidak nyata terhadap fase pertumbuhan vegetatif dan umur berbunga serta umur berbuah, tetapi konsentrasi MOL $200 \quad \mathrm{~mL}^{-1} \quad \mathrm{~L}^{-1}$ secara konsisten memberikan hasil tanaman yang terbaik.

\section{KESIMPULAN}

1. Interaksi antara pupuk hayati mikoriza dan konsentrasi MOL bonggol dan batang pisang berbeda nyata terhadap bobot segar dan bobot kering buah. Mikoriza dengan dosis $10 \mathrm{~g}$ tanaman $^{-1}$ dan MOL dengan konsentrasi $200 \mathrm{~mL} \mathrm{~L}^{-1}$ merupakan dosis mikoriza dan konsentrasi MOL yang memberikan bobot segar dan bobot kering buah terbaik, yaitu 303,14 dan 36,86 g.

2. Pengaruh dosis mikoriza berbeda nyata terhadap bobot segar, bobot kering, diameter, dan panjang buah. Mikoriza $10 \mathrm{~g}$ tanaman $^{-1}$ merupakan dosis terbaik terhadap bobot segar buah, yaitu 229,42 g dan bobot kering buah, yaitu 26,77 g.

3. Pengaruh konsentrasi MOL bonggol dan batang pisang berbeda nyata terhadap jumlah buah per tanaman, bobot segar, bobot kering, diameter, dan panjang buah. Konsentrasi 200 $\mathrm{mL}$ MOL $\mathrm{L}^{-1}$ merupakan konsentrasi MOL yang memberikan bobot buah segar dan bobot kering buah terbaik, masing-masing 256,53 dan 29,98 g.

\section{DAFTAR PUSTAKA}

Alex, S. (2013). Sayuran dalam Pot. Sayuran Konsumsi Tak Harus Beli. Yogyakarta: Pustaka Baru Press.

Badan Penelitian dan Pengembangan Pertanian Kementerian Pertanian. (2015). Menghitung Takaran Pupuk Untuk Percobaan Kesuburan Tanah. Hlmn. 91-105. Dipublikasikan pada Petunjuk Teknis Pelaksanaan Penelitian Kesuburan Tanah.

Budiyani, Ni Komang, Ni Nengah Soniasari, \& Ni Wayan Sri Sutari. (2016). Analisis Kualitas Larutan Mikroorganisme Lokal (MOL) Bonggol Pisang. E-Jurnal Agroekoteknologi Tropika, 5(1): 6372.

Eliyani, Susylowati, \& Nazari, A.P.D. (2018). Pemanfaatan limbah rumah tangga sebagai pupuk organik cair pada tanaman bawang merah (Allium cepa var. ascalonicum (L.) Back) . Agrifor, 17(2): 249-262.

Goenadi, D.H. \& Saraswati, R. (1993). Kemampuan Melarutkan Fosfat dari Beberapa Isolat Fungi Pelarut Fosfat. Menara Perkebunan, 61(3): 61-66.

Hardjowigeno, S. (1995). Ilmu Tanah. Edisi Revisi. Jakarta: Akademika Pressindo.

Harjadi, M.M.S.S. (1979). Pengantar Agronomi. Jakarta: Gramedia.

Kementerian Pertanian Republik Indonesia. Data Lima Tahun Terakhir. https://www.pertanian.go.id/home/?sh $\mathrm{ow}=$ page $\&$ act $=$ view $\& \mathrm{id}=61$.

Killham, K. (1994). Soil Ecology. Cambridge University Press. 
Kurnia, Gusti Ayu Maya. (2014). Pupuk Organik. Dinas Pertanian Kabupaten Buleleng. https://distan.bulelengkab.go.id/inform asi/detail/artike1/pupuk-organik-84.

Maspary. (2012). Apa Kehebatan MOL Bonggol Pisang. http://www.gerbangpertanian.com/201 2/05/apa-kehebatan-mol-bonggolpisang.html.

Matondang, A.M., Syafruddin, \& Jumini. (2020). Pengaruh Jenis dan Dosis Pupuk Hayati Mikoriza Terhadap Pertumbuhan dan Hasil Tanaman Cabai (Capsicum annuum) pada Tanah Andosol Lembah Seulawah Aceh Besar. Jurnal Ilmiah Mahasiswa Pertanian, 5(2): 101-110.

Purwasasmita, M. \& Kunia, K. (2009). Mikroorganisme Lokal sebagai Pemicu

Siklus Kehidupan dalam Bioreaktor Tanaman. Seminar Nasional Teknik Kimia Indonesia- SNTKI 2009. Bandung 19-20 Oktober 2009.

Resti, Z., Sulyanti, E., \& Reflin. (2019). Konsorsium Bakteri Endofit Sebagai Pengendali Hayati Ralstonia solanacearum dan Pemacu Pertumbuhan Tanaman Cabai. Prosiding Seminar Nasional Masyarakat Biodiversity Indonesia, 4(2): 208-214.

Salisbury, F.B. \& Ross, C.W. (1995). Fisiologi Tumbuhan. (Lukman, D.R. \& Sumarsono). Bandung: ITB.
Solaiman, M.Z., \& H. Hirata. (1995). Effect Of Indigenous Arbuscular Mycorrhizal Fungi In Paddy Fields On Rice Growth And NPK Nutrition under different water Regimes. Soil Sci. Plant Nutr., 41(3): 505-514.

Subiksa, I.G.M. (2002). Pemanfaatan Mikoriza Untuk Penanggulangan Lahan Kritis. Makalah Falsafah Sains Program Pasca Sarjana Institut Pertanian Bogor. Bogor.

Suhastyo, A.A. (2011). Studi Mikrobiologi dan Sifat Kimia Mikroorganisme Lokal (MOL) yang Digunakan pada Budidaya Padi Metode SRI (System of Rice Intensification). Tesis. Sekolah Pascasarjana Institut Pertaniah Bogor. Bogor.

Surtinah. 2007. Kajian Pertumbuhan Vegetatif dengan Produksi Tomat (Lycopersicum esculentum Mill.). Jurnal Ilmiah Pertanian Universitas Lancang Kuning . 4(1): 1-7.

Thomas, R.S., Franson, R.L. \& Bethlenfalvay, G.J. (1993). Separation of Arbuscular Mycorrhizal Fungus and Root Effect on Soil Aggregation. Soil Sci. Soc. Am. J., 57: 77-81.

Zulaikha, S. \& Gunawan. (2006). Serapan Fosfat dan Respon Fisiologis Tanaman Cabai Merah Cultivar Hot Beauty Terhadap Mikoriza dan Pupuk Fosfat pada Tanah Ultisol. Bioscientiae, 3(2): 83-92. 